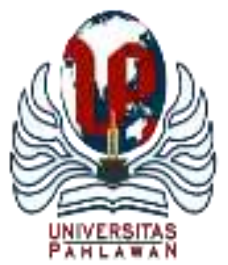

Edukatif : Jurnal Ilmu Pendidikan Volume 3 Nomor 5 Tahun 2021 Halm 3277 - 3286

EDUKATIF: JURNAL ILMU PENDIDIKAN

Research \& Learning in Education

https://edukatif.org/index.php/edukatif/index

\title{
Pengembangan Modul Bahasa Indonesia Materi Puisi Menggunakan Model Mind Mapping di Sekolah Dasar
}

\author{
Noviyanti $^{1 凶}$, Agustina Tyas Asri Hardini $^{2}$ \\ Universitas Kristen Satya Wacana, Indonesia ${ }^{1,2}$ \\ E-mail : $292017069 @$ student.uksw.edu $^{1},{\underline{\text { agustina.hardini@ } u_{k s w . e d u}}}^{2}$
}

\begin{abstract}
Abstrak
Penelitian ini bertujuan untuk mengembangkan produk Bahasa Indonesia materi puisi kelas $\mathrm{V}$ dengan penerapan model mind mapping di sekolah dasar. Metode penelitian yan digunakan adalah penelitian RnD modul yang dikembangkan adalah pembelajran Bahasa Indonesia materi puisi dalam bentuk modul, modul ini dikembangkan unruk pembelajaran materi puisi lebih lengkap. Modul pembelajaran akan diuji oleh pakar materi, media dan kurikulum. Penelitian dilakukan dalam 3 tahap yaitu, studi pendahuluan, studi pengembangan model, dan studi uji model. Hasil penelitian yang diperoleh penerapan model mind mapping dapat meningkatkan hasil belajar kelas $\mathrm{V}$ sekolah dasar dengan uji validasi yang dilakukan oleh 3 pakar meliputi pakar materi, pakar media dan pakar kurikulum. Penelitian dinyatakan berhasil jika hasil uji dari ahli materi, ahli media dan ahli kurikulum persentase lebih dari $61 \%$ hasil yang didapat dari ahli materi mendapat persentase rata-rata sebesar 82,3\% dengan kategori sangat tinggi. Hasil uji validasi ahli media yang dilakukan oleh ahli media mendapatkan persentase rata-rata sebesar 94,6\% dengan kategori sangat tinggi. Sedangkan uji validasi ahli kurikulum yang dilakukan oleh ahli kurikulum mendapatkan persentase rata- rata sebesar 76,48\% dengan kategori tinggi. Berdasarkan hasil uji ketiga pakar maka modul layak digunakan untuk membantu pembelajaran materi puisi untuk kelas $\mathrm{V}$ sekolah dasar.
\end{abstract}

Kata Kunci: modul Puisi, Sekolah Dasar.

\begin{abstract}
This study aims to develop Indonesian products for fifth grade poetry material by applying mind mapping models in elementary schools. The research method used is RnD research. The module that was developed is learning Indonesian poetry material in the form of modules, this module was developed for more complete learning of poetry material. The learning modules will be tested by material, media and curriculum experts. The research was conducted in 3 stages, namely, a preliminary study, a model development study, and a test model study. The results obtained from the application of the mind mapping model can improve learning outcomes for grade V elementary school with validation tests conducted by 3 material experts, media experts and curriculum experts. The research is declared successful if the test results from material experts, media experts and curriculum experts are more than $61 \%$ the results obtained from material experts get an average percentage of $82.3 \%$ with a very high category. The results of the media expert validation test conducted by media experts got an average percentage of $94.6 \%$ with a very high category. Meanwhile, the curriculum expert validation test conducted by the curriculum expert obtained an average percentage of $76.48 \%$ in the high category. Based on the test of the three experts, the appropriate module is used to help learning poetry material for grade Velementary school
\end{abstract} Keywords: module, Poetry, Elementary School.

Copyright (c) 2021 Noviyanti, Agustina Tyas Asri Hardini

$\triangle$ Corresponding author

Email :292017069@student.uksw.edu

DOI : https://doi.org/10.31004/edukatif.v3i5.1271

ISSN 2656-8063 (Media Cetak)

ISSN 2656-8071 (Media Online)

Edukatif : Jurnal Ilmu Pendidikan Vol 3 No 5 Tahun 2021 p-ISSN 2656-8063 e-ISSN 2656-8071 
3278 Pengembangan Modul Bahasa Indonesia Materi Puisi Menggunakan Model Mind Mapping di Sekolah Dasar - Noviyanti, Agustina Tyas Asri Hardini

DOI: https://doi.org/10.31004/edukatif.v3i5.1271

\section{PENDAHULUAN}

Bahasa Indonesia merupakan bahasa pengantar di semua jenjang pendidikan dari sekolah dasar hingga perguruan tinggi. Permendikbud No. 69 Tahun 2013 tentang Kerangka Dasar dan Struktur Kurikulum Sekolah Menengah Atas "Tujuan Kurikulum 2013 adalah mempersiapkan manusia Indonesia agar kemampuan hidup sebagai pibadi yang beriman, produktif, kreatif, inovatif dan afektif. Dan mampu berkontribusi pada kehidupan bermasyarakat berbangsa, bernegara dan peradaban dunia". Pembelajaran bahasa Indonesia di SD diarahkan untuk meningkatkan siswa dalam berkomunikasi secara lisan maupun tulisan, karena kegiatan berbahasa dalam kehidupan manusia menggunakan bahasa lisan dan tulisan.

Keterampilan berbahasa yang termasuk kedalam komunikasi secara lisan adalah keterampilan berbicara dan menyimak, sedangkan keterampilan berbahasa yang termasuk ke dalam berkomunikasi secara tulisan adalah keterampilan membaca dan menulis. Salah satu aspek keterampilan berbahasa yang sangat penting yaitu, keterampilan menulis. Melalui tulisan seseorang dapat mengungkapkan pikiran dan gagasannya untuk mencapai suatu tujuan tertentu. Salah satu materi pembelajaran keterampilan menulis memiliki berbagai macam bentuk, diantaranya adalah menulis puisi.

Ruang lingkup pembelajaran bahasa indonesia meliputi empat ketrampilan berbahasa yaitu, menulis, membaca, mendengarkan dan berbicara. Menulis puisi merupakan salah satu hal yang penting bagi siswa, karena dengan pembelajaran puisi siswa akan mengenal sastra sebagai sarana untuk menuangkan ide-ide ataupun imajinasi terhadap sesuatu. Oleh karena itu, salah satu cara melestarikan puisi dilaksanakan melalui pembelajaran bahasa Indonesia di sekolah dasar. Namun, kenyataannya keterampilan menulis puisi kurang mendapat perhatian khusus. Namun pada kenyataannya kemampuan menulis dalam bahasa Indonesia masih rendah. Hal tersebut diperkuat oleh (Soni, 2006) menjelaskan bahwa kesulitan dan hambatan yang dihadapi siswa saat menulis narasi sebagai berikut: 1) kesulitan dalam menemukan ide, biasanya berawal xdari ketidaktahuan siswa untuk menulis apa dan darimana memulai menuliskan berbagai ide yang terkandung dalam pikiran siswa. Sehingga sebagai siswa tidak dapat menuliskan ide pokok dalam buku sampai berakhirnya waktu; 2) kesulitan dalam mengembangkan ide, kesulitan dalam merangkai kata kalimat dengan tepat, siswa terkadang merasa bahwa tulisannya tidak sesuai yang diharapkan.

Berdasarkan pengamatan awal di SD ditemukan pemasalahan mengenai ketrampilan menulis puisi hal ini dipenaruhi oleh beberapa faktor yaitu: 1) pembelajaran masih berpusat pada guru, siswa cenderung belum kreatif; 2) sumber belajar terbatas pada buku pegangan guru; 3) siswa belum mampu menyampaikan gagasan dalam bentuk tulisan; 4) pembelajaran menulis puisi di sekolah belum menggunakan model yang sesuai. Data awal yang didapat untuk hasil belajar siswa Bahasa Indonesia semester 1 tahun ajaran 2020/2021 siswa kelas V SDN kopeng 03 kecamatan Getasan dari 22 siswa di kelas terdapat 6 siswa yang nilainya dibawah KKM dan 16 di atas KKM. KKM bahasa Indonesia yang telah ditetapkan oleh sekolah adalah 75, dengan adanya data tersebut. Dengan demikian maka dari perlu adanya inovasi pembelajaran untuk meningkatkan ketrampilan menulis puisi.

Berdasarkan permasalahan tersebut maka dibutuhkan bahan ajar yang dapat mengatasi berbagai permasalahan yang ada. Salah satu bahan ajar selain buku yang bisa digunakan untuk mendukung pelaksanaan pembelajaran adalah modul. Modul menurut (Setiyadi, 2017) diperkuat oleh Muhammad dan Ismail modul merupakan sebuah bahan ajar yang disusun secara sistematis dengan menggunakan bahasa yang dapat dengan mudah dipahami oleh siswa serta dapat dipelajari secara mandiri tanpa membutuhkan seorang fasilitator. Puisi adalah karya sastra yang menggunakan kata-kata indah dan kaya makna (Hetilaniar, 2019).

Berdasarkan penjelasan diatas, dibutuhkan bahan ajar yang digunakan dalam pembelajaran yang mampu memberikan gambaran terkait materi puisi, untuk mempermudah siswa dalam memahami puisi. Agar dapat mengatasi permasalahan yang ada, maka dikembangkan produk penelitian yaitu modul pembelajaran Bahasa Indonesia materi puisi. 
3279 Pengembangan Modul Bahasa Indonesia Materi Puisi Menggunakan Model Mind Mapping di Sekolah Dasar - Noviyanti, Agustina Tyas Asri Hardini

DOI: https://doi.org/10.31004/edukatif.v3i5.1271

Berdasarkan uraian diatas, penelitian ini bertujuan mengembangkan produk pembelajaran Bahasa Indonesia materi puisi kelas V SD dan keterampilan menulis puisi dengan model mind mapping dan didukung dengan pengembangan modul yang dapat digunakan oleh guru dan siswa.

\section{METODE PENELITIAN}

Penelitian ini menggunakan jenis penelitian pengembangan (Research And Development/ R\&D). Dalam penelitian ini menggunakan model menurut Sukmadinata, dkk (2006:169) modifikasi dari Borg dan Gall dengan metode penelitian dengan jenis data kualitatif. Sepuluh langkah penelitian dan pengembangan dari Brog dan Gall disingkat menjadi 3 tahap yaitu, pendahuluan, pengembangan model, dan uji model. Setiap langkah memiliki langkah operasional yaitu tahap pendahuluan meliputi studi pustaka, studi lapangan, dan penyususnan produk; tahap pengembangan meliputi pengembangan produk awal, uji ahli, uji coba terbatas, dan uji coba lebih luas; serta tahap pengujian.

Instrumen penilaian yang digunakan dalam penelitian ini berupa instrumen penilaian ahli. Instrumen tersebut akan diberikan kepada validator ahli. Jenis data yaitu data kualitatif yang diperoleh dari instrumen penilaian ahli pada uji ahli materi, ahli media dan ahli kurikulum. Pengisian rubrik ahli materi, ahli media dan ahli kurikulum dilakukan oleh 3 orang ahli yaitu 1 ahli materi dosen dari pendidikan guru sekolah dasar, 1 ahli media dosen dari pendidikan guru sekolah dasar, dan 1 ahli kurikulum dosen pendidikan sejarah yang memiliki kepakaran dibidang Bahasa Indonesia. Hasil yang didapatkan berupa kritik dan saran perbaikan terhadap modul pembelajaran Bahasa Indonesia materi puisi. Data yang telah didapat dari uji validasi ahli dilakukan analisis untuk menjawab apakah modul pembalajaran Bahasa Indonesia materi puisi yang dikembangkan layak digunakan. Skor yang diperoleh dari uji validasi ahli, dipersentasekan dalam rumus berikut:

$A P=$ Skor AktualSkor Ideal $\times 100 \%$ AP $=\frac{\text { Skor Aktual }}{\text { Skor Ideal }} \times 100 \%$

Keterangan :

AP : Angka Persetase

Skor Aktual : Skor yang diberikan oleh validator ahli

Skor Ideal : Skor maksimal hasil kali jumlah item dari masing-masing item.

Angka yang diperoleh dan sudah dipersentasekan kemudian dikelompokkan kedalam kategori berikut: Tabel 1. Kategori Uji Validasi

\begin{tabular}{ll}
\hline Interval & Kategori \\
\hline $81-100 \%$ & Sangat Tinggi \\
\hline $61-80 \%$ & Tingi \\
\hline $41-60 \%$ & Cukup \\
\hline $21-40 \%$ & Rendah \\
\hline $1-20 \%$ & Sangat Rendah \\
\hline
\end{tabular}

Hasil dan uji validasi ahli materi dalam model pembelajaran Bahasa Indonesia materi puisi dapat dikatakan layak untuk di uji cobakan apabila persetase mencapai kategori tinggi yaitu $\geq 61 \%$ (Mawardi, 2014:113). 
3280 Pengembangan Modul Bahasa Indonesia Materi Puisi Menggunakan Model Mind Mapping di Sekolah Dasar - Noviyanti, Agustina Tyas Asri Hardini

DOI: https://doi.org/10.31004/edukatif.v3i5.1271

\section{HASIL DAN PEMBAHASAN PENELITIAN}

Penelitian ini hanya berhenti pada tahap uji ahli. Uji validasi dilakukan oleh ahli materi, ahli media dan ahli kurikulum. Dalam pengembangan modul pembelajaran Bahasa Indonesia materi puisi untuk meningkatkan hasil belajar siswa kelas V SD menggunakan model menurut Sukmadinata, dkk (2006:169) modifikasi dari Borg dan Gall yaitu, studi pustaka, studi pengembangan, dan studi penguji.

\section{Tahap Studi Pustaka}

Pada tahap ini dilakukan wawancara dengan guru kelas V SDN Kopeng 03. Ditemukan permasalahan yaitu buku yang digunakan dalam pembelajaran Bahasa Indonesia materi puisi belum dapat membantu siswa dalam memahami materi pembelajaran. Kemudian dilakukan studi pustaka berkaitan dengan model penelitian dan pengembangan Research and Development (R\&D) dan model pengembangan Sukmadinata. Pada tahap studi lapangan dilaksanakan survey lapangan untuk mendapatkan informasi mengenai kebutuhan produk. Tahap ini dilaksanakan melalui kegiatan wawancara dengan Bapak Dhenny Priantono Christyawan S.Pd selaku pengajar kelas V SDN Kopeng 03 terkait dengan proses pembelajaran serta ketersediaan dari sumber belajar yang digunakan untuk mendukung proses pembelajaran. Dari hasil wawancara pada pembelajaran Bahasa Indonesia khususnya materi puisi didapatkan siswa mengalami kesulitan dalam menentukan judul dan tema. Buku yang ada juga belum membuat siswa memahami. Selain itu ketika siswa dihadapkan dalam soal menentukan tema puisi, maka siswa akan mengalami kebingungan dan kesulitan.

\section{Tahap Studi Pengembangan}

Pada tahap ini modul pembelajaran Bahasa Indonesia materi puisi dilakukan validasi oleh ahli media, dan ahli materi. Tahap ini dilakukan untuk menentukan kelayakan modul pembelajaran Bahasa Indonesia materi puisi. Apabila terdapat permasalahan yang diberikan melalui kritik dan saran, maka modul pembelajaran Bahasa Indonesia materi puisi akan direvisi terlebih dahulu sebelum diuji cobakan kepada siswa dalam uji coba terbatas.

\section{Tahap Studi Pengujian}

Pada tahap ini modul pembelajaran Bahasa Indonesia untuk menguji produk. Dalam penelitian ini uji produk media pembelajaran apakah dapat meningkatkan hasil belajar siswa. Dalam pelaksanaan uji produk dilakukan dengan menggunakan metode Penelitian Tindakan Kelas yang dilaksanakan dengan 2 siklus. Uji coba lebih luas dilakukan terhadap siswa kelas V SD Negeri Kopeng 03, Sebelum pembelajaran dilakukan pretest terlebih dahulu kemudian pembelajaran dilaksanakan dan menggunakan modul pembelajaran Bahasa Indonesia materi puisi. Setelah pembelajaran selesai dilakukan diberikan posttest kemudian diadakan analisis stastik uji perbedaan. Uji perbedaan dihitung antara hasil posttest siklus 1 dan hasil posttest siklus 2 sekolah tersebut, akan tetapi dalam penelitian ini hanya samapi uji terbatas.

Berikut adalah hasil produk pengembangan modul pembelajaran Bahasa Indonesia materi puisi:

Tabel 2. Spesifikasi Produk

\begin{tabular}{lc}
\hline No $\quad$ Komponen & Visual \\
\hline A. Pendahuluan & \\
\hline $1 . \quad$ Sampul & \\
\hline
\end{tabular}



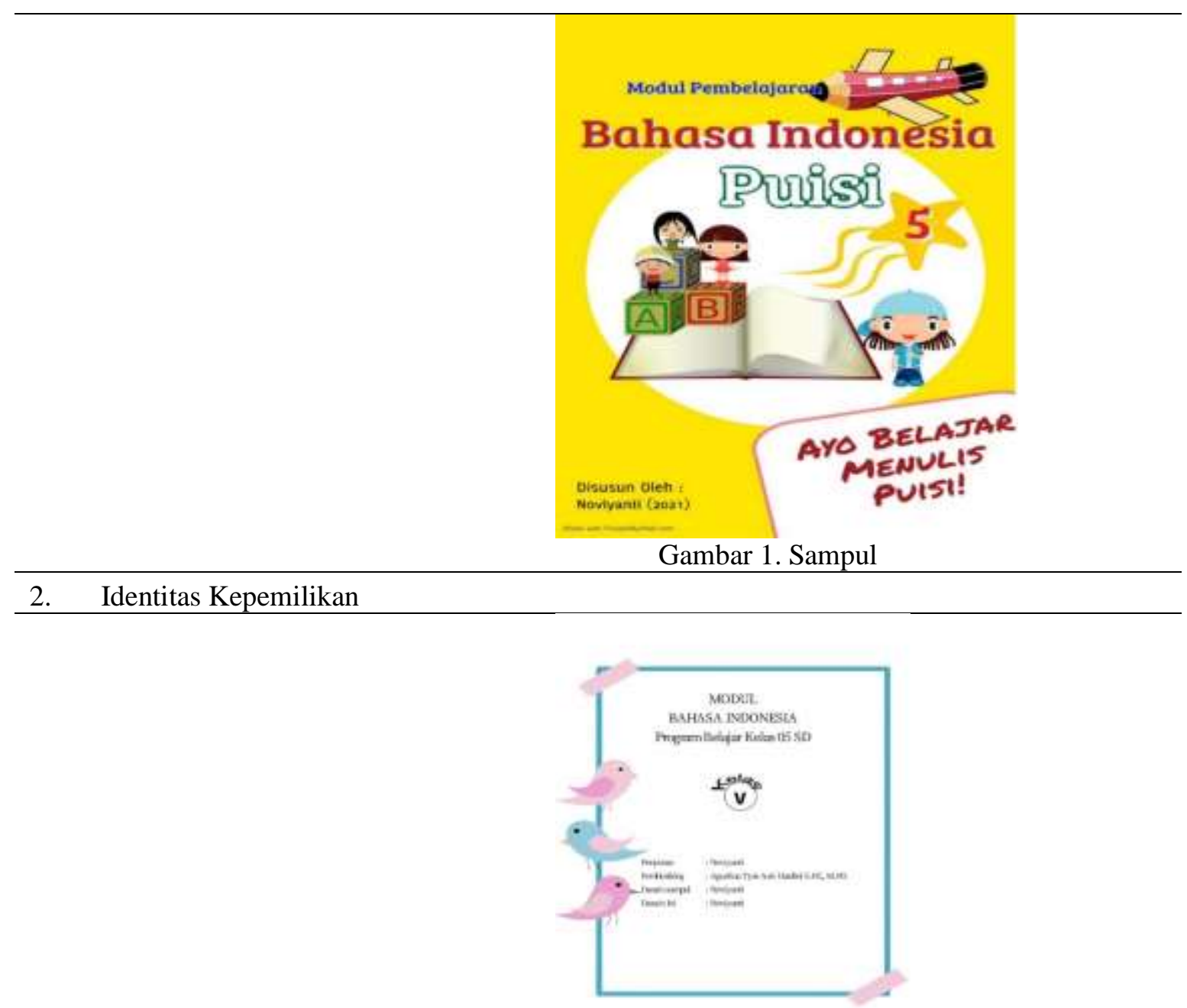

Gambar 2. Identitas Kepemilikan

3. Kata Pengantar

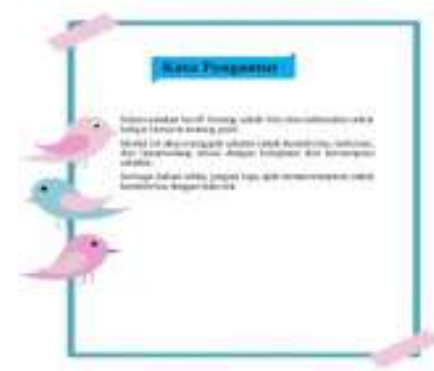

Gambar 3. Kata Pengantar

4. Daftar Isi 


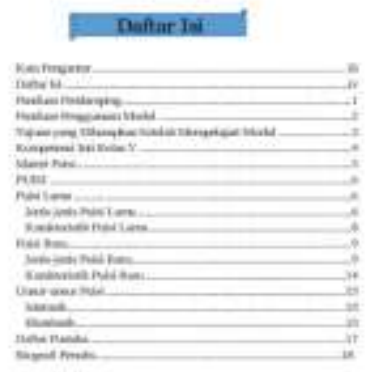

Gambar 4. Daftar Isi

\section{Panduan Pendamping}

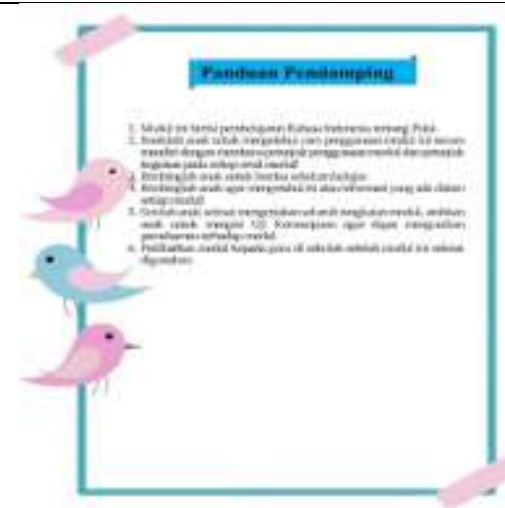

Gambar 5. Panduan Pendamping

6. Panduan Penggunaan Modul

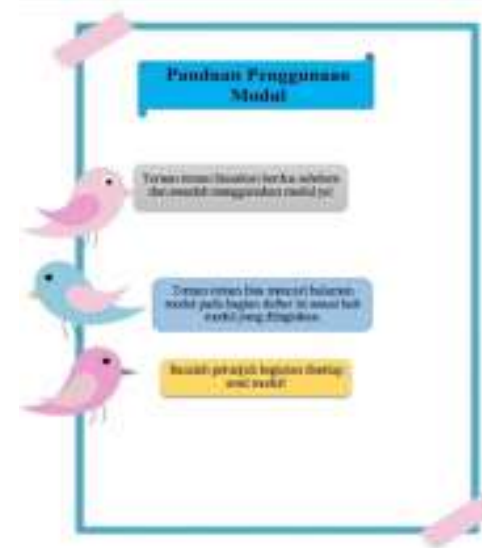

Gambar 6. Panduan Penggunaan Modul

7. Tujuan Pembelajaran Modul 


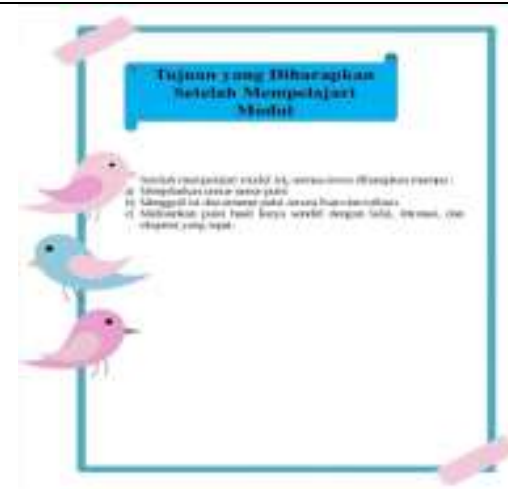

Gambar 7. Tujuan Pembelajaran Modul

B. Isi

8. Kompetensi Inti

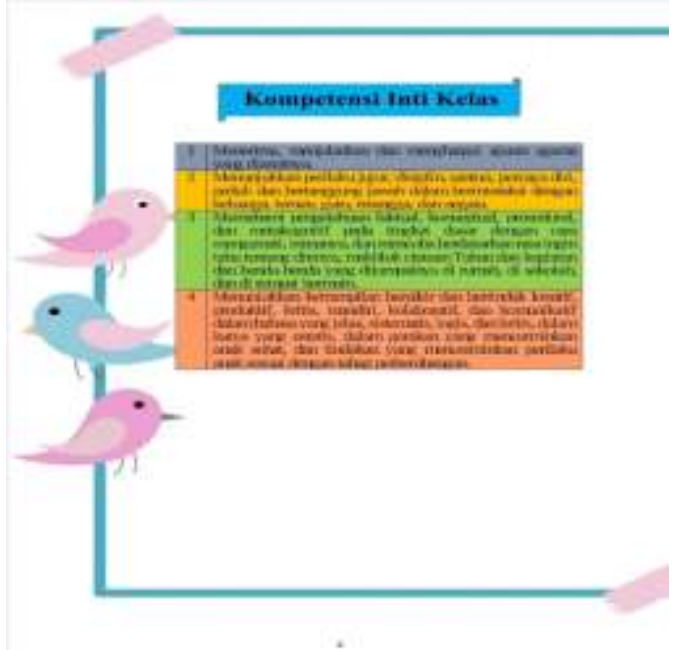

Gambar 8. Kompetensi Inti

9. Uraian Materi

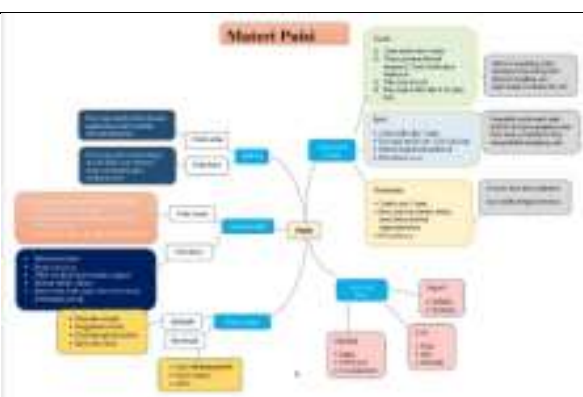

Gambar 9. Uraian Materi

\section{Penutup}

10. Daftar Pustaka 


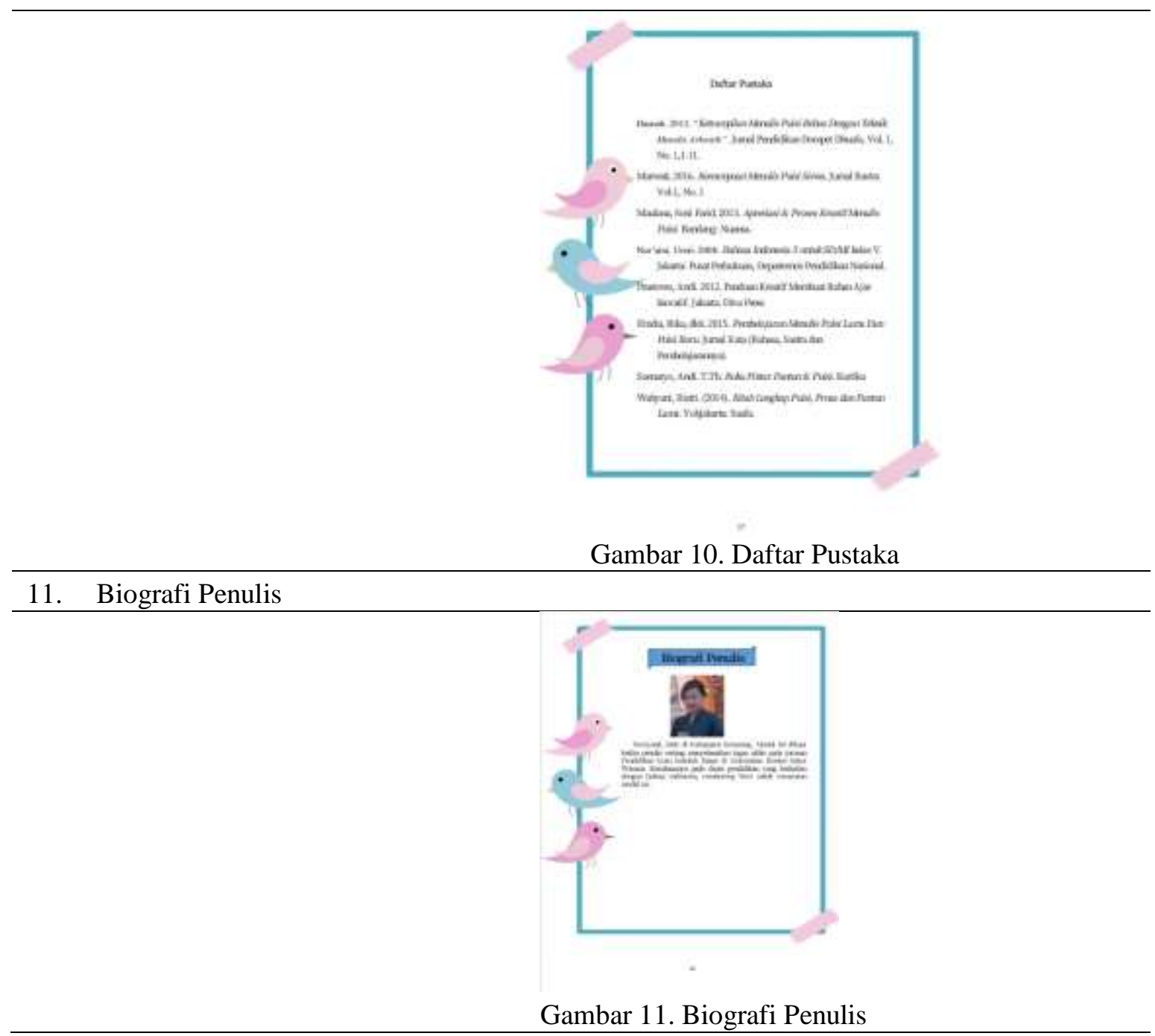

Penelitian pengembangan ini mengembangkan modul pembelajaran Bahasa Indonesia materi puisi. Pembahasan tingkat validasi modul pembelajaran Bahasa Indonesia materi puisi dengan skoe sebagai berikut:

Tabel 3. Hasil Uji Validasi Ahli

\begin{tabular}{lclll}
\hline Validator & Skor Ideal & $\begin{array}{l}\text { Skor } \\
\text { Aktual }\end{array}$ & AP & Kategori \\
\hline Ahli Materi & 68 & 56 & $82,35 \%$ & Sangat Tinggi \\
\hline Ahli Media & 94 & 89 & $94,68 \%$ & Sangat Tinggi \\
\hline Ahli Kurikulum & 68 & 52 & $76,46 \%$ & Tinggi \\
\hline
\end{tabular}

Sesuai dengan artikel penelitian pengembangan modul pembelajaran Bahasa Indonesia, materi puisi juga meningkatkan hasil belajar siswa. dapat dilihat dari beberapa hasil uji yang telah dilakukan yaitu uji ahli materi, media dan kurikulum dengan hasil sebagai berikut: (1) uji materi mendapatkan skor 56 dengan persetase $82,35 \%$ kategori sangat tinggi;(2) uji ahli media mendapatkan skor 89 dengan persentase 94,68\% kategori sangat tinggi;(3) uji ahli kurikulum mendapat skor 52 dengan persentase 76,46\% kategori tinggi. Hasil kategori tersebut dapat dinyatakan bahwa modul pembelajaran Bahasa Indonesia materi puisi layak digunakan setelah dilakukan perbaikan sesuai dengan saran ahli materi, ahli media dan ahli kurikulum. 
Hasil uji validasi dari ketiga ahli pada pengembangan modul pembelajaran Bahasa Indonesia materi puisi siswa kelas V SD berhasil, penggunaan media mind mapping bisa menjadi salah satu media baru untuk meningkatkan hasil belajar siswa. Pernyataan tersebut di dukung oleh hasil penelitian pengembangan yang dilakukan Nur Azizah pada tahun 2016. Diperoleh bahwa modul pembelajaran Bahasa Indonesia untuk siswa kelas III layak digunakan. Hal tersebut ditunjukkan dari didapatkannya skor rata-rata $80 \%$ yang merupakan hasil validasi ahli materi dari ahli Bahasa Indonesia yang berarti sangat layak, dan diperoleh skor rata-rata $84 \%$ pada validasi media yang berarti sangat layak pada uji ahli yang dilakukan pada siswa Madrasah Ibtidaiyah Darussalamah.

Kelebihan dari modul pembelajaran Bahasa Indonesia materi puisi adalah, 1)media yang paling mudah digunakan. 2)media yang mudah dalam mengembangkan kemampuan siswa 3)gambar yang menarik untuk membuat siswa senang saat pelaksanaan pembelajaran. Kelemahan dari modul pembelajaran Bahasa Indonesia materi puisi adalah 1)tidak dapat mengakomodasi siswa dengan kemampuan baca terbatas.

\section{KESIMPULAN}

Penelitian ini menimpulkan bahwa penelitiaan R\&D (Research and Development) yang diperoleh dengan penerapan mind mapping dapat meningkatkan hasil belajar siswa hal ini terbukti dari uji ahli materi, ahli media, dan ahli kurikulum. Hasil yang didapatkan dari uji validasi ahli materi mendapatkan persentase rata-rata sebesar $82,35 \%$ dengan kategori sangat tinggi. Sedangkan uji validasi media mendapatkan persetase rata-rata sebesar 94,65\% dengan kategori sangat tinggi. Dan uji validasi kurikulum mendapatkan persetase rata-rata sebesar 76,46\% dengan kategori tinggi. Sehingga modul pembelajaran Bahasa Indonesia materi puisi yang telah dikembangkan layak digunakan untuk pembelajaran puisi pada siswa kelas 5 sekolah dasar.

\section{UCAPAN TERIMA KASIH}

Peneliti bersyukur kepada Tuhan Yang Maha Esa yang telah memberi kelancaran dan kemudahan dalam membuat serta menyelesaikan artikel ini. Tak lupa berterima kasih kepada Bapak Suroyo dan Ibu Lasmini yang telah memberikan semangat dan dukungan. Terima kasih kepada dosen pembimbing Ibu Agustina Tyas Asri Hardini, S.Pd., M.Pd. yang telah meluangkan waktu untuk memberikan bimbingan dan juga arahan yang sangat berguna untuk dapat menyelesaikan artikel ini. Terima kasih kepada teman-teman RS17C dan juga para sahabat dan teman yang telah memberikan motivasi, memberi semngat dan dukungan atas terselesaikannya artikel ini.

\section{DAFTAR PUSTAKA}

Puisi, M., Kelas, S., Di, V., \& Negeri, S. M. P. (2013). Yang Diperoleh Lebih Besar Dari T. 2, 1-11.

Setiyadi, M. W. (2017). Pengembangan Modul Pembelajaran Biologi Berbasis Pendekatan Saintifik Untuk Meningkatkan Hasil Belajar Siswa. Journal Of Educational Science And Technology (Est), 3(2), 102. Https://Doi.Org/10.26858/Est.V3i2.3468

Soni, I. B. (2006). Meningkatkan Kemampuan Siswa Kelas V Sd Inpres Mayayap Dalam Menulis Karangan Narasi Melalui Model Pembelajaran Kooperatif. 5(1), 53-61.

A, A. W. P. \& M. (N.D.). Analisis Kelayakan Bahasa Dalam Buku Teks Tema 1 Kelas 1 Sekolah Dasar. Kurikulum 2013.

A, B. B. \& P. F. (2015). Effrots To Improve Counting Skill Using Number Card Displayers. Raja Grafindo Persada. 
3286 Pengembangan Modul Bahasa Indonesia Materi Puisi Menggunakan Model Mind Mapping di Sekolah Dasar - Noviyanti, Agustina Tyas Asri Hardini

DOI: https://doi.org/10.31004/edukatif.v3i5.1271

Azizah, N. (2016). Pengembangan Media Pembelajaran Buku Bergambar Pada Mata Pelajaran Bahasa Indonesia Materi Menulis Puisi Kelas Iii Madrasah Ibtidaiyah Darussalaman. Universitas Islam Negeri Maulana Malik Ibrahim.

Badan Standar Nasional Pendidikan. (2006). Lampiran Permendiknas Nomor 22 Tahun 2006.

Departemen Pendidikan Nasional. (2006). Kurikulum Sekolah Dasar Kelas V.

Departemen Pendidikan Nasional. (2008). Panduan Pengembangan Bahan Ajar.

D, S. O. A. P. (2013). Effect Of Mind-Mapping As A Self-Regulated Learning Strategy On Students Achievement In Basic Science And Technology. 4(6), 163-172. Https://Doi.Org/10.5901/Mjss.2013.V4n6p163

Ekowati, D. W., Kusumaningtyas, D. I., \& Sulistyani, N. (2017). Ethnomathematica Dalam Pembelajaran Matematika ( Pembelajaran Bilangan Dengan Media Batik Madura , Tari Khas Trenggal Dan Tari Khas Madura ). 5(September), 716-721.

H, G. T. (2008). Menulis Sebagai Suatu Ketrampilan Berbahasa (Revisi). Angkasa.

Huda, M. (2014). Model - Model Pengajaran Dan Pembelajaran. Pustaka Media Offset.

Mawardi, M. (2014). Model Desain Pembelajaran Konsep Dasar Pkn Berbasis Belajar Mandiri Mengunakan Moodle. Widya Sari Press.

M, T. S. \& R. (N.D.). Implementasi Pendidikan Nilai Dalam Pembelajaran Ips.

Mukh, D. (2014). Pengembangan Materi Puisi Di Sd. Jurnal Bahasa Dan Sastra Indonesia, X Nomor 1.

Norwita, A. (2014). Penggunaan Pendekatan Scientific Berbasis Mind Mapping Untuk Meningkatkan Kemampuan Menulis Puisi. Jurnal Pendidikan, 3 Nomor 4, 210-214.

Nugroho, P. (2017). Internalisasi Nilai - Nilai Dan Kepribadian Mahasiswa Pendidikan Agama Islam Melalui Humanis-Religus Edukasia. Jurnal Penelitian Pendidikan Islam, 355-382.

Pendidikan, J. W., Febriani, F., Sunaryo, Y., Ciamis, G., \& Indonesia, U. P. (2020). Https://Jurnal.Unigal.Ac.Id/Index.Php/Jwp Peningkatan Kemampuan Representasi Matematis Siswa Melalui Model Pembelajaran Scaffolding 1,3. 7(1), 39-44.

Permendiknas. (2006). Tentang Standar Isi Untuk Satuan Pendidikan Dasar Dan Menengah.

Poerwati, S. I. Dan J. I. (2015). Penggunaan Mind Map Untuk Meningkatkan Keterampilan Menulis Puisi Disekolah Dasar. 2 Nomor 2, 94-99.

Simangkalit, A. N. \&. (2015). Pengaruh Penggunaan Media Pembelajaraan Mind Mapping Terhadap Presetasi Belajar Matematika Siswa Kelas Vii Smp Tunas Baru Jin - Seung Batam Tahun Ajaran 2014/2015. Jurnal Studi Progam Matematika, 5 (1).

Siswa, K., Di, S. D., \& Ciamis, K. (2020). Https://Jurnal.Unigal.Ac.Id/Index.Php/Jwp Pengembangan Model Pembelajaran Ips Bersasis Buku Cerita Masyarakat Adat Kampung Kuta Dalam Pengelolaan Sumber Daya Alam Untuk Membentuk Karakter Siswa Sd Di Kabupaten Ciamis. 7(1), 45-52.

Sugiyono. (2009). Kualitatif Dan R\&D. Bandung: Alfabeta.

Sugiyono. (2016). Metode Penelitian \& Pengembangan Research And Development. Bandung: Alfabeta.

Zakariah, M. A. (N.D.). Metode Penelitian Kualitatif, Kuantitatif, Dan R\&D 